\title{
PENGARUH LINGKUNGAN FISIK , PELAYANAN KONSUMEN DAN PROMOSI TERHADAP KEPUASAN NASABAH MENABUNG PADA PT. BANK DANAMON INDONESIA CABANG BUKITTINGGI
}

\author{
Indra Syafrin \\ Universitas Putra Indonesia YPTK Padang, Indonesia \\ Indra Syafrin@yahoo.co.id
}

\begin{abstract}
ABSTRAK
Penelitian ini bertujuan untuk membuktikan, (1) Pengaruh Lingkungan Fisik terhadap kepuasan nasabah menabung di Bank Danamon Indonesia Cabang Bukittinggi,(2) Pelayanan Konsumen terhadap kepuasan nasabah menabung di Bank Danamon Indonesia Cabang Bukittinggi,(3) Promosi terhadap kepuasan nasabah menabung di Bank Danamon Indonesia Cabang Bukittinggi. Populasi dalam penelitian ini adalah nasabah Bank Danamon Indonesia Cabang Bukittinggi berjumlah 4.446 nasabah. Pengambilan sample dengan menggunakan rumus statistik slovin, dimana metode ini dapat menggambarkan sebagian dari populasi yang ada, sehingga diperoleh samplingnya sebanyak 106 nasabah. Hasil dari penelitian ini dengan menggunakan beberapa metoda analisis, diantaranya analisis regresi linier berganda dan analisis uji hipotesis. Dalam uji analisis regresi linier berganda, semua variabel menunjukan bahwa adanya pengaruh variabel lingkungan fisik, pelayanan konsumen dan promosi secara positif terhadap kepuasan nasabah menabung di PT. Bank Danamon Indonesia Cabang Bukittinggi. Meskipun pengaruh dari lingkungan fisik relatif kecil .Begitu juga dengan uji hipotesis secara parsial variabel pelayanan nasabah dan promosi keduanya mempunyai pengaruh positif dan signifikan terhadap kepuasan nasabah sedangkan variabel lingkungan fisik menunjukan bahwa variabel tersebut berpengaruh positif terhadap kepuasan nasabah namun tidak signifikan. Uji hipotesis secara simultan ketiga variabel tersebut mempunyai pengaruh positif terhadap kepuasan nasabah.
\end{abstract}

Kata Kunci : Lingkungan fisik,Pelayanan konsumen, Promosi dan Kepuasan nasabah

\section{PENDAhuluan}

Semakin hari persaingan dalam dunia bisnis kian ketat terutama di bidang pelayanan dan jasa, hal ini dapat terlihat dari bermunculannya usaha yang bergerak di bidang jasa, bersamaan dengan hal tersebut banyak perusahaan jasa khususnya jasa keuangan perbankan yang sudah banyak bermunculan di Bukittinggi dan sekitarnya sehingga membuat persaingan semakin lebih ketat. Terkadang banyak perusahaan yang bergerak pada bidang jasa dan pelayanaan perbankan kurang memperhatikan kepuasan nasabahnya. Sebuah perusahaan yang bergerak pada bidang jasa dan pelayanan keuangan perbankan harus mengutamakan nilai kepuasan nasabahnya terhadap jasa pelayanan yang telah mereka berikan. Kepuasan nasabah sangat berpengaruh terhadap kemajuan perusahaan perbankan itu sendiri,oleh karena itu perusahaan yang bergerak pada bidang jasa dan pelayanan keuangan perbankan khususnya pada PT. Bank Danamon Indonesia Cabang Bukittinggi, harus lebih mengutamakan pelayanan yang baik, baik dari segi keamanan, kenyamanan serta fasilitasfasilitas yang diberikan oleh PT. Bank Danamon Indonesia Cabang Bukittinggi itu sendiri yang dapat membuat nasabah merasa puas.

Beberapa perbankan lainnya sudah menyadari tentang peluang ini, maka para perbankan telah membuka cabangnya di Bukittinggi. Seperti Bank Negara Indonesia, Bank Rakyat Indonesia, Bank Mega, Bank Central Asia, Bank Mandiri, dan lainya, kesemua bank ini mampu menyerap banyak nasabah. Oleh sebab itu PT. Bank Danamon Indonesia Cabang Bukittinggi mencoba untuk mempertahankan nasabahnya dengan memberikan pelayanan yang baik sehingga nasabah merasa puas. 
Permasalahan yang terjadi pada PT. Bank Danamon Indonesia Cabang Bukittinggi saat ini adalah masalah kepuasan nasabah. Fenomena ini muncul karena kurang nyaman dan kurang menariknya penampilan fisik gedung seperti letak gedung,desain, warna yang kurang menarik, banking hall yang kurang nyaman,mesin ATM yang kadang kadang tidak berfungsi, pelayanan customer service yang kurang ramah dan pelayanan teller yang lama serta promosi yang kurang menarik.

Faktor penyebab munculnya fenomena masalah ini dibuktikan banyaknya rekening nasabah yang tidak aktif lagi ( dorman ). Hal ini disebabkan karena nasabah tidak pernah datang lagi lebih dari enam bulan berturut turut untuk bertransaksi baik setor maupun tarik dana di Bank Danamon Cabang Bukittinggi,sehingga jumlah rekening dorman dari bulan ke bulan mengalami peningkatan. Rekening tidak aktif ini ada dua jenis yaitu rekening tidak aktif saldo nol dan rekening tidak aktif bersaldo. Rekening tidak aktif saldo nol, dimana nasabah sama sekali tidak pernah datang ke bank sejak buka rekening atau beberapa kali datang namun setelah itu tidak pernah datang kembali lebih dari enam bulan dan menyediakan saldo hanya sebanyak saldo minimal sebesar Rp. 50.000,- ( lima puluh ribu rupiah ) saldo tersebut akan dikenakan biaya biaya seperti biaya administrasi dan biaya saldo dibawah minimal, hingga rekening tersebut bersaldo nol .Rekening yang sudah bersaldo nol tidak bisa ditutup oleh sistem bank, kecuali atas permintaan pemilik rekening. Sedangkan rekening tidak aktif bersaldo dimana nasabah tidak pernah bertransaksi lebih dari enam bulan namun memiliki saldo diatas saldo minimal. Rekening tidak aktif bersaldo inilah yang seharusnya didata ulang dan dihubungi kembali nasabah yang bersangkutan.

Adapun pengaruh dari rekening pasif atau dorman ini terhadap bank adalah sebagai berikut :

1. Berpotensi menurunkan jumlah dana pihak ketiga

2. Menurunkan tingkat loyalitas nasabah

3. Menurunkan jumlah keuntungan bank

Berikut tabel data jumlah rekening tidak aktif ( dorman ) pada Bank Danamon Cabang Bukittinggi sampai dengan bulan Agustus 2016.

\begin{tabular}{|c|c|c|c|c|}
\hline Keterangan & $\begin{array}{c}\text { Rekening } \\
\text { Aktive }\end{array}$ & $\begin{array}{c}\text { Rekening } \\
\text { Passive }\end{array}$ & $\begin{array}{c}\text { Total } \\
\text { Rekening }\end{array}$ & $\begin{array}{c}\% \text { Rekening } \\
\text { Passive }\end{array}$ \\
\hline Jumlah Rekening & 1.776 & 2.670 & 4.446 & $60 \%$ \\
\hline
\end{tabular}

Dari tabel diatas menunjukan bahwa jumlah rekening passive ( dorman ) mengalami jumlah yang cukup significant yaitu mencapai $60 \%$, dari jumlah rekening yang ada. Hal ini menunjukan lemahnya pengelolaan pemeliharaan rekening nasabah dan kurangnya hubungan komunikasi pelayanan terhadap nasabah yang ada. Dari data tabel diatas juga dapat di jelaskan bahwa peningkatan jumlah rekening passive disebabkan kurangnya informasi yang diterima nasabah pada saat pembukaan rekening di bank seperti adanya biaya biaya yang akan di kenakan terlalu tinggi dibandingkan bank pesaing sehingga menimbulkan kekecewaan nasabah. Kekecewaan inilah salah satunya yang berimplikasi pada timbulnya rekening passive pada PT. Bank Danamon Indonesia Cabang Bukittinggi.

Perkembangan dan pertambahan nasabah dan upaya dari PT. Bank Danamon Indonesia Cabang Bukittinggi untuk mempertahankan nasabahnya inilah yang membuat penulis tertarik untuk melakukan penelitian mengenai kepuasan pelanggan lebih lanjut

\section{LANDASAN TEORI}

\section{1. Lingkungan atau sarana fisik}

Lingkungan atau Sarana fisik ( Physical Evidence), merupakan hal yang nyata yang turut mempengaruhi keputusan konsumen untuk membeli dan menggunakan produk atau jasa yang ditawarkan. Lingkungan Fisik (Physical Evidence) memberikan kesempatan istimewa kepada perusahaan dalam mengirimkan pesan-pesan yang kuat dan konsisten berkenaan dengan apa yang ingin dicapai, diberikan perusahaan kepada segmen pasar yang dituju, serta pesan-pesan 
berkenaan dengan karakteristik jasa yang dimiliki. Lingkungan fisik juga sangat penting dalam membentuk image atau persepsi karena melalui lingkungan fisik ini konsumen siap untuk mengidentifikasikan dan membandingkan suatu perusahaan jasa dengan perusahaan jasa lainnya. Menurut Lupiyoadi, (2008:77) Physical Evidence atau bukti fisik merupakan lingkungan fisik tempat jasa diciptakan dan langsung berinteraksi dengan konsumen. Menurut Ratih Hurriyati (2010:64) : "Sesuatu hal yang secara nyata turut mempengaruhi keputusan konsumen untuk membeli dan menggunakan produk jasa yang ditawarkan".Menurut Lovelock (2011:17) dimensi dari physical evidence yaitu "buildings, landscaping, vehicles, interior furnishing, equipment, staff members, signs, printed materials, and other visible cues all provide tangible evidence of a firm's service quality.

\subsection{Pelayanan Konsumen}

Jasa atau pelayanan adalah setiap tindakan atau kegiatan yang ditawarkan oleh suatu pihak kepada pihak lain, yang pada dasarnya tidak terwujud dan tidak mengakibatkan kepemilikan apapun. Produksinya dapat dikaitkan atau tidak dengan suatu produk fisik (Kotler, 2005:486).

Jasa mencakup semua aktivitas ekonomi yang hasilnya bukanlah produk atau konstruksi fisik, yang secara umum konsumsi dan produksinya dilakukan pada saat bersamaan, dan nilai tambah yang diberikannya dalam bentuk (kenyamanan, hiburan, kecepatan, dan kesehatan) yang secara prinsip tidak berwujud pada pembeli pertamanya (Zeithaml, 2003:3).

Pelayanan disektor perbankan khususnya di front liners menurut Sumarni (1997) secara garis besar terdiri dari ketanggapan pelayanan, kecepatan transaksi, keberadaan pelayanan dan profesionalisme. Ketanggapan pelayanan meliputi kegiatan dalam melayani nasabah dengan cepat dan tanggap, termasuk juga menangani persoalan, pertanyaan dan keluhan yang dihadapi nasabah. Selain ketanggapan pelayanan, kecepatan transaksi juga memegang peranan penting dalam pemberian pelayanan di front liner.

Menurut Assauri (1999: 149) definisi pelayanan adalah bentuk pemberian yang diberikan oleh produsen baik terhadap pelayanan barang yang diproduksi maupun terhadap jasa yang ditawarkan guna memperoleh minat konsumen, dengan demikian pelayanan mempengaruhi minat konsumen terhadap suatu barang atau jasa dari pihak perusahaan yang menawarkan produk atau jasa.

Pelayanan adalah proses pemenuhan kebutuhan melelui aktivitas orang lain secara langsung.(Moenir,1992:16)

Suatu pelayanan akan terbentuk karena adanya proses pemberian layanan tertentu dari pihak penyedia layanan kepada pihak yang dilayani. (Brata, 2003 : 9)Penekanan terhadap definisi pelayanan diatas adalah pelayanan yang diberikan menyangkut segala usaha yang dilakukan oleh seseorang dalam rangka mencapai tujuan guna untuk mendapatkan kepuasan dalan hal pemenuhan kebutuhan

\subsection{Promosi}

Kriyantono (2008). Mengemukakan bahwa iklan merupakan bentuk komunikasi non-personal yang menjual pesan-pesan secara persuasif dari sponsor yang jelas guna untuk mempengaruhi orang agar membeli produk dengan membayar biaya untuk media yang digunakan.

Durianto (2003). Mendefinisikan iklan sebagai proses komunikasi yang tujuannya untuk membujuk atau menggiring orang agar mengambil tindakan yang menguntungkan bagi pihak pembuat iklan.Lee (2004). Menurutnya, iklan ialah sebuah komunikasi komersil dan nonpersonal tentang sebuah organisasi dan produk-produknya yang ditransmisikan ke khalayak ramai dengan target melalui media yang bersifat massal seperti televisi, radio, koran, majalah, direct mail (pengeposan langsung), reklame luar ruang, atau kendaraan umum.

Menurut Saladin (2003): Promosi adalah salah satu unsur dalam bauran pemasaran perusahaan yang didayagunakan untuk memberitahukan, mengingatkan, dan membujuk konsumen tentang produk perusahaan. 
Menurut Zimmerer (2002): Promosi adalah segala macam bentuk komunikasi persuasi yang dirancang untuk menginformasikan pelanggan tentang produk atau jasa dan untuk memengaruhi mereka agar membeli barang atau jasa tersebut yang mencakup publisitas, penjualan perorangan dan periklanan. Menurut Fandy Tjiptono ( 2008;219) promosi merupakan salah satu faktor penentu keberhasilan suatu program pemasaran untuk memberikan informasi mengenai adanya suatu produk. Menurut Dharmesta dan Irawan ( 2007;79) promosi adalah arus informasi atau persuasi satu arah yang dibuat untuk mengarahkan seseorang atau organisasi kepada tindakan yang menciptakan pertukaran dalam pemasaran.Menurut Buchari Alma ( 2000;135) promosi adalah bentuk komunikasi pemasaran yang merupakan aktivitas pemasaran yang berusaha menyebarkan informasi,mempengaruhi dan mengingatkan pasar sasaran atas perusahaan dan produknya agar bersedia menerima, membeli dan loyal pada produk yang ditawarkan perusahaan yang bersangkutan.Menurut Philip Kotler ( 2006 ) promosi adalah semua kegiatan yang dilakukan perusahaan untuk mengkomunikasi dan mempromosikan produknya kepada pasar sasaran.

Betapapun berkualitasnya suatu produk, bila konsumen belum pernah mendengarnya dan tidak yakin bahwa produk itu akan berguna bagi mereka, maka mereka tidak akan pernah membelinya. Pentingnya promosi dapat diibaratkan seorang pria ganteng berkaca mata hitam yang dari tempat gelap pada malam kelam mengedipkan matanya pada seorang gadis cantik di kejauhan. Tak seorangpun yang tahu apa yang dilakukan pria tersebut selain dirinya sendiri.

Pada hakekatnya promosi adalah suatu bentuk komunikasi pemasaran yaitu aktivitas pemasaran yang berusaha menyebarkan informasi, mempengaruhi, mengingatkan pada pasar sasaran atas perusahaan dan produknya agar bersedia menerima, membeli dan loyal pada produk yang ditawarkan perusahaan yang bersangkutan.

Dari beberapa pengertian promosi di atas, maka dapat kita simpulkan bahwa promosi merupakan kegiatan pemasaran dan penjualan dalam rangka menginformasikan dan mendorong permintaan terhadap produk, jasa, dan ide dari perusahaan dengan cara memengaruhi para konsumen agar mau membeli produk dan jasa yang dihasilkan oleh perusahaan.

\subsection{Kepuasan Konsumen}

Syarat yang harus dicapai oleh suatu perusahaan agar dapat sukses dalam persaingan adalah berusaha mencapai tujuan untuk menciptakan dan mempertahankan pelanggan ( levit,1987 ). Agar tujuan tersebut tercapai, maka setiap perusahaan harus berupaya menghasilkan dan menyampaikan barang dan jasa yang diinginkan konsumen dengan harga yang pantas ( reasonable ). Dengan demikian,setiap perusahaan harus mampu memahami perilaku konsumen pada pasar sasarannya, karena kelangsungan hidup perusahaan tersebut sebagai organisasi yang berusaha memenuhi kebutuhan dan keinginan para konsumen sangat tergantung pada perilaku konsumenya.

Perilaku konsumen sendiri merupakan tindakan-tindakan individu yang secara langsung terlibat dalam usaha memperoleh,menggunakan, dan menentukan produk dan jasa, termasuk proses pengambilan keputusan yang mendahului dan mengikuti tindakan-tindakan tersebut ( Engel et al.1990 ). Dari pengertian tersebut dapat diketahui bahwa pemahaman terhadap perilaku konsumen bukanlah pekerjaan yang mudah, tetapi cukup sulit dan kompleks. Hal ini disebabkan oleh banyaknya variabel yang mempengaruhi dan variable variable tersebut cenderung saling berinteraksi. Meskipun demikian, bila hal tersebut dapat dilakukan maka perusahaan yang bersangkutan akan dapat meraih keuntungan yang jauh lebih besar dari pada para pesaingnya, karena dengan dipahaminya perilaku konsumenya, perusahaan dapat memberikan kepuasan secara lebih baik kepada konsumennya ( Kotler,et al,1996 )

Berdasarkan landasan teori yang telah ditelaah diatas, maka model kerangka pemikiran teoritis yang dikembangkan pada penelitian ini terlihat pada gambar berikut : 


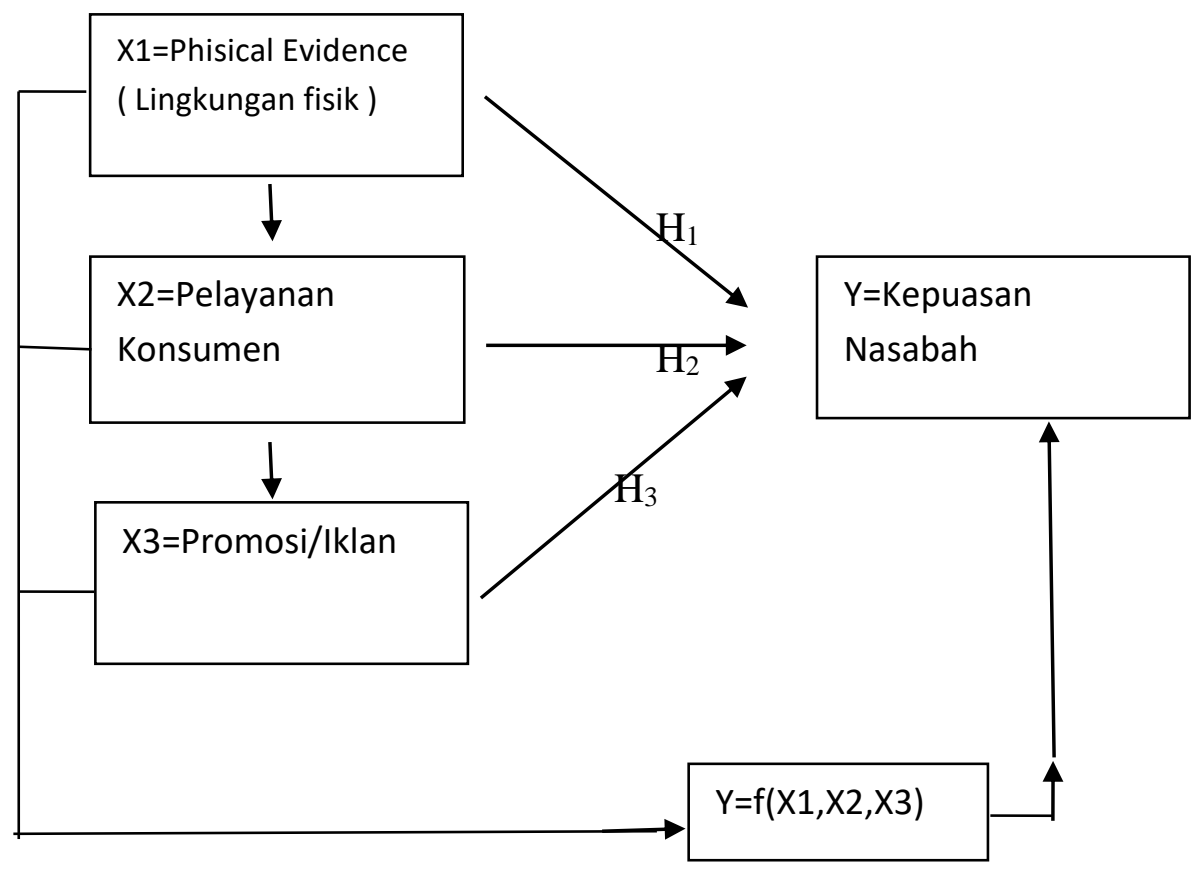

Gambar 1

\section{METODOLOGI PENELITIAN}

Metode penelitian adalah suatu teknis atau cara mencari, memperoleh, mengumpulkan atau mencatat data, baik yang berupa data primer maupun data sekunder yang digunakan untuk keperluan menyusun suatu karya ilmiah dan kemudian menganalisa faktor-faktor yang berhubungan dengan pokok-pokok permasalahan sehingga akan terdapat suatu kebenaran data-data yang akan diperoleh. Pengertian metode penelitian menurut Sugiyono (2008:4), menyatakan bahwa metode penelitian adalah sebagai berikut :"Metode Penelitian pada dasarnya merupakan cara ilmiah untuk mendapatkan data yang valid dengan tujuan dapat ditemukan, dibuktikan, dan dikembangkan suatu pengetahuan sehingga pada gilirannya dapat digunakan untuk memahami, memecahkan dan mengantisipasi masalah". Dalam hal tekhnik pengumpulan data pada penelitian ini, tekhnik yang digunakan adalah melakukan survei lapangan. Survei ini dilakukan dengan cara pengisian kuesioner oleh nasabah yang diambil sampelnya. Kuesioner tersebut telah ditentukan jawabannya, responden hanya memilih satu dari beberapa jawaban yang ada.

\section{HASIL ANALISIS DAN PEMBAHASAN 4.1 Pengaruh Lingkungan fisik}

Hasil regresi linier berganda pada table I diatas ditemukan bahwa koefisien regresi lingkungan fisik $\mathrm{b}_{1}$ $=0,049$ artinya nilai lingkungan fisik tersebut berpengaruh positif terhadap kepuasan nasabah sebesar 0.143. Jika pelayanan konsumen dan promosi dianggap tetap dan kualitas lingkungan fisik semakin tinggi, maka semakin tinggi pula rasa kepuasan nasabah

Hasil uji t pada table I untuk variabel X1 yaitu lingkungan fisik diperoleh nilai hitungnya 0,341 dan tingkat $P$ Value 0.734. Dengan menggunakan batas signifikan $\alpha=5 \%(0,05)$ maka di dapat $t$ tabel sebesar 1.659 ( lihat tabel t ) maka $\mathrm{P}$ Value $>\alpha$ atau $\mathrm{T}_{\text {hitung }}<\mathrm{T}_{\text {tabel }}$, artinya $\mathrm{H}_{0}$ diterima dan $\mathrm{H}_{1}$ ditolak. Dengan demikian maka hipotesis uji t variabel lingkungan fisik berpengaruh secara positif terhadap kepuasan nasabah tetapi tidak diterima 


\subsection{Pengaruh Pelayanan konsumen}

Hasil regresi linier berganda pada table I diatas ditemukan bahwa koefisien regresi pelayanan konsumen $\mathrm{b}_{2}=1.064$ artinya nilai pelayanan nasabah sebesar tersebut berpengaruh positif terhadap kepuasan nasabah sebesar 0.122. Jika lingkungan fisik dan promosi dianggap tetap dan kualitas pelayanan nasabah semakin tinggi, maka semakin tinggi pula rasa kepuasan nasabah Hasil uji t pada tabel I untuk variabel X2 yaitu pelayanan nasabah/konsumen diperoleh nilai hitungnya 8.714 dan tingkat $P$ Value 0.000 . Dengan menggunakan batas signifikan $\alpha=5 \% \quad(0,05$ ) maka di dapat $T_{\text {tabel }}$ sebesar 1.659 ( lihat tabel $t$ ) maka $P$ Value $<\alpha$ atau $T_{\text {hitung }}>T_{\text {tabel }}$ artinya $H_{0}$ ditolak dan $\mathrm{H}_{1}$ di terima. Dengan demikian maka hipotesis uji $\mathrm{t}$ variabel pelayanan nasabah/konsumen berpengaruh secara positif terhadap kepuasan nasabah dan dapat diterima. Arah koefisien regresi positif artinya pelayanan konsumen memiliki pengaruh signifikan secara parsial terhadap kepuasan nasabah. Sehingga dapat disimpulkan bahwa indikator pelayanan konsumen yang semakin baik, akan memberikan kepuasan nasabah.

\subsection{Pengaruh Promosi}

Hasil regresi linier berganda pada table I diatas ditemukan bahwa koefisien regresi pelayanan promosi $b_{3}=0.371$ artinya nilai promosi tersebut berpengaruh positif terhadap kepuasan nasabah sebesar 0.114. Jika lingkungan fisik dan pelayanan konsumen dianggap tetap dan kualitas promosi semakin tinggi, maka semakin tinggi pula rasa kepuasan nasabah

Hasil uji t pada tabel I untuk variabel X3 yaitu promosi diperoleh nilai hitungnya 3.244 dan tingkat $\mathrm{P}$ Value $=0.002$. Dengan menggunakan batas signifikan $\alpha=5 \%(0,05)$ maka di dapat $\mathrm{T}_{\text {tabel }}$ sebesar 1.659 ( Lihat Daftar Tabel $\mathrm{t}$ ) maka $\mathrm{P}$ Value $<\alpha$ atau $\mathrm{T}_{\text {hitung }}>\mathrm{T}_{\text {tabel }}$ artinya $\mathrm{H}_{0}$ ditolak dan $\mathrm{H}_{1}$ di terima. Dengan demikian maka hipotesis uji t variabel promosi berpengaruh secara positif terhadap kepuasan nasabah dan dapat diterima. Arah koefisien regresi positif artinya promosi memiliki pengaruh signifikan secara parsial terhadap kepuasan nasabah. Sehingga dapat disimpulkan bahwa indikator variabel promosi yang semakin baik, akan memberikan kepuasan nasabah.

\subsection{Pengujian secara simultan ( Uji F )}

Pengujian secara simultan ( uji f) digunakan untuk mengetahui secara bersama sama ( simultan ) pengaruh variabel independen ( Lingkungan fisik, Pelayanan Konsumen dan Promosi ) terhadap variabel dependen ( Kepuasan Nasabah ).Signifikan pengaruh positif yang dapat di estimasi dengan membandingkan $P$ Value dan $\alpha=5 \% \quad(0,05)$ atau nilai $F_{\text {tabel }}$ dan $F_{\text {hitung. }}$.

Untuk menganalisa pengujian secara simultan ini, dapat digunakan tabel ANOVA yang di olah dari SPSS 17, sebagaimana yang terlihat pada Tabel II

Dari tabel II diatas dapat dijelaskan analisisnya sebagai berikut :

$\mathrm{H} 0 ; \beta 1 ; \beta 2=0$ secara bersama sama variabel bebas tidak berpengaruh positif terhadap variabel terikat. Dari hasil uji $\mathrm{F}$ untuk variabel bebas diperoleh nilai $\mathrm{F}_{\text {hitung }}=33.533$ dengan tingkat $P V$ alue $=0.000$. Dengan menggunakan batas significant $\alpha=0.05$ ( 5\%) maka didapat $\mathrm{F}_{\text {tabel }}$ sebesar 2,69 ( lihat tabel F ). Hal ini dapat di jelaskan bahwa $F_{\text {hitung }}>F_{\text {tabel }}$ atau PValue $<\alpha$ yang artinya $\mathrm{H}_{0}$ ditolak dan $\mathrm{H}_{1}$ diterima. Maka hipotesis uji $\mathrm{F}$ menyimpulkan bahwa secara bersama sama variabel independen berpengaruh positif terhadap variabel dependen. Arah anova uji F positif artinya Lingkungan Fisik, Pelayanan Konsumen dan Promosi berpengaruh signifikan secara simultan terhadap kepuasan nasabah. 


\subsection{Analisis Data Dan Uji Hipotesis}

Analisis data pada penelitian ini menggunakan analisis regresi linier berganda yaitu suatu analisa yang digunakan untuk melihat pengaruh faktor faktor yang mempengaruhi kepuasan nasabah, dalam hal ini adalah untuk melihat sejauh mana kemampuan variable independen yang terdiri dari lingkungan fisik (X1), pelayanan konsumen(X2) dan promosi(X3) mempengaruhi variable dependen yaitu kepuasan nasabah (Y). Disamping itu sebelum dilakukan analisis regresi linier berganda juga telah dilakukan pengujian asumsi klasik yang terdiri dari multikolinieritas, heteroskodasitas dan normalitas. Kemudian penelitian ini juga menggunakan uji hipotesis yang terdiri dari uji serempak ( Uji F ) dan uji parsial ( Uji T ) dimana uji hipotesis ini digunakan untuk mengetahui apakah seluruh variable independen terdiri dari lingkungan fisik (X1), pelayanan konsumen(X2) dan promosi(X3) secara bersama sama mempunyai pengaruh yang kuat terhadap variable dependen yaitu kepuasan nasabah (Y).Berikut ringkasan hasil pengujian analisis regresi liner berganda, sebagaimana yang tampak pada tabel dibawah ini :

Tabel 1

\begin{tabular}{|l|r|r|r|r|r|}
\hline \multicolumn{1}{|c|}{ Model } & $\begin{array}{c}\text { Unstandardized } \\
\text { Coefficient }\end{array}$ & & $\begin{array}{l}\text { Standardized } \\
\text { Coefficient }\end{array}$ & $\mathrm{t}$ & \multicolumn{1}{c|}{ Sig } \\
\hline & \multicolumn{1}{|c|}{$\mathrm{B}$} & Std Error & Beta & & \\
\hline 1.Constant & $-0,134$ & 2.842 & & $-0,047$ & 0.962 \\
\hline Lingkungan Fisik (X1) & 0.049 & 0.143 & 0.024 & 0.341 & 0.734 \\
\hline Pelayanan Konsumen (X2) & 1.064 & 0.122 & 0.622 & 8.714 & 0.000 \\
\hline Promosi iklan (X3) & 0.371 & 0.114 & 0.236 & 3.244 & 0.002 \\
\hline
\end{tabular}

Sumber : Data Olahan dari SPSS 17, 2016

Berdasarkan tabel I diatas maka dapat disajikan persamaan regresi sebagai berikut :

$Y=-0.134 b o+0.049 X_{1}+1.064 X_{2}+0.371 X_{3}+2.842$

TABEL II

"ANOVA b،

\begin{tabular}{|l|r|r|r|r|l|}
\hline \multicolumn{1}{|c|}{ Model } & Sum of Square & \multicolumn{1}{c|}{ Df } & Mean Square & \multicolumn{1}{c|}{ F } & \multicolumn{1}{c|}{ Sig } \\
\hline Regression & 1569.085 & 3 & 523.028 & 33.533 & $.000^{\text {a }}$ \\
\hline Residual & 1590.915 & 102 & 15.597 & & \\
\hline Total & 3160.000 & & & & \\
\hline
\end{tabular}

Sumber data : Diolah dari SPSS 17,2016

\section{KESIMPULAN}

Berdasarkan hasil penelitian yang dilakukan maka dapat disimpulkan beberapa hal yang penting dalam penelitian ini yaitu :

1. Ditemukan adanya hubungan pengaruh lingkungan fisik seperti tata letak gedung,banking hall , mesin ATM, dan lain lain dengan kepuasan nasabah namun tidak memiliki konstribusi terhadap kepuasan tersebut dan tidak signifikan pada PT Bank Danamon Indonesia Cabang Bukittinggi.

2. Pelayanan nasabah/konsumen baik ucapan dengan sopan, informasi produk bank, penanganan keluhan nasabah dan lain lain, berpengaruh secara positif terhadap kepuasan nasabah dan dapat diterima. Arah koefisien regresi positif, artinya pelayanan konsumen memiliki pengaruh signifikan secara parsial terhadap kepuasan nasabah. Sehingga dapat disimpulkan bahwa indikator variabel pelayanan konsumen yang semakin baik, akan memberikan kepuasan nasabah semakin baik pada PT Bank Danamon Indonesia Cabang Bukittinggi. 
3. Promosi dalam bentuk iklan dan pemberian hadiah secara langsung maupun undian, berpengaruh secara positif terhadap kepuasan nasabah dan dapat diterima. Arah koefisien regresi positif artinya promosi memiliki pengaruh signifikan secara parsial terhadap kepuasan nasabah.Sehingga dapat disimpulkan bahwa indikator variabel promosi yang semakin baik, akan memberikan kepuasan nasabah semakin baik pada PT Bank Danamon Indonesia Cabang Bukittinggi.

\section{DAFTAR PUSTAKA}

Assauri ,1999, Manajemen Pemasaran: Dasar, Konsep dan Strategi, PT. Raja Grafindo Persada, Jakarta.

Buchari Alma ,2000, Manajemen Pemasaran dan Pemasaran Jasa,PT Prehallindo,Jakarta

Brata, 2003,Dasar-dasar Pelayanan Prima. Bumi Aksara,Jakarta

Dharmesta dan Irawan ,2007,_Manajemen Pemasaran Modern,Liberty, Yogyakarta.

Durianto,2003, Invasi Pasar dengan Iklan yang Efektif: Strategi, Program, dan Teknik Pengukuran. Gramedia Pustaka Utama, Jakarta.

Engel et al.1990, Consumer Behavior, 6 th ed, Chicago

Fandy Tjiptono ,2008, Strategi Pemasaran,Andy Offset. Yokyakarta

Kotler,et al,1996,_Manajemen Pemasaran,PT. Prenhallindo, Jakarta

Kotler, 2005, Manajemen Pemasaran, Jilid I dan II, PT.Indeks,Jakarta

Kriyantono, 2008, Teknik Praktis Riset Komunikasi, Alfabeta, Bandung

levit,1987, The Danger of Social Responsibility, Ethical Theory and Business

Lee ,2004, Prinsip-Prinsip Pokok Periklanan Dalam Perspektif Global. Prenada Media.

Lupiyoadi, 2008:Manajemen Pemasaran Jasa, Salemba Empat,Jakarta

Lovelock, 2011:Manajemen Pemasaran Jasa, Alih bahasa Agus Widyantoro, PT.Index ,Jakarta

Moenir,1992,_Manajemen Pelayanan Umum di Indonesia,Bumi Aksara, Jakarta

Philip Kotler,2006, Manajemen Pemasaran, Jild I dan II, Edisi kesebelas,PT Indeks, Gramedia,Jakarta.

Saladin ,2003, Manajemen Pemasaran, Bandung

Sumarni ,1997, Pengantar Bisnis, Liberty, Yogyakarta

Ratih Hurriyati ,2010, Bauran Pemasaran dan Loyalitas Konsumen, Alfabeta, Bandung

Sugiyono,2008,_Metode Penelitian Kuantitatif Kualitatif dan R\&D, Alfabeta,Bandung.

Zimmerer ,2002,_Essentials of Entrepreneurship and Small Business Management

Zeithaml, 2003, Service Marketing, Prentice Hall, exclusive right by Me graw Hill 